\title{
Methods for the Determination of $\mathrm{As}, \mathrm{Cd}$, and $\mathrm{Pb}$ in Potato Slurry Using Multivariate Optimization and Graphite Furnace Atomic Absorption Spectrometry
}

\author{
Reginaldo Ferreira de Oliveira ${ }^{a}$, Waldomiro Borges Neto ${ }^{b}$, Cláudia Carvalhinho Windmöller ${ }^{a}$, \\ Mark Anthony Beinnerc, and José Bento Borba da Silva ${ }^{\text {a* }}$ \\ ${ }^{a}$ Institute of Mathematical Sciences, Department of Chemistry, Federal University of Minas Gerais, \\ Belo Horizonte, Minas Gerais, Brazil \\ ${ }^{b}$ Institute of Chemistry, Federal University of Uberlândia, Uberlândia, Minas Gerais, Brazil \\ c School of Nursing and Nutrition, Federal University of Minas Gerais, Belo Horizonte, MG, Brazil
}

\begin{abstract}
This study presents the development and validation of a method for the determination of arsenic (As), cadmium (Cd), and lead $(\mathrm{Pb})$ in potato slurry samples using graphite furnace atomic absorption spectrometry (GFAAS) after multivariate optimization. The slurries were prepared by cryogenic grinding, sieving, and addition of $2 \%(\mathrm{v} / \mathrm{v})$ nitric acid and $1 \%(\mathrm{v} / \mathrm{v})$ hydrogenous peroxide up to a 2 -mL volume. The slurries were kept homogeneous using air bubbling with an aquarium pump. Iridium $(500 \mu \mathrm{g})$ and titanium were the best permanent modifiers for As, $\mathrm{Cd}$, and $\mathrm{Pb}$. Factorial design was used to obtain the best modifiers, pyrolysis and atomization temperatures for all analytes. After that a central composition design (CCD) was made, to obtain the
\end{abstract}

\section{INTRODUCTION}

The potato plant (Solanum tuberosum) is an herbaceous annual that grows up to $100 \mathrm{~cm}$ (40 inches) tall and produces a tuber so rich in starch that it ranks as the world's fourth most important food after rice, wheat, and maize (1).

Given its importance on the world stage, especially with population growth and related problems,

Corresponding autbor.

E-mail: bentojb@yaboo.com.br

Tel: +553134095750

Fax: +553134095700 best pyrolysis and atomization temperatures.

The accuracy was evaluated by recovery tests over three different days $(n=21)$ and the results varied from 97.4 to $102.8 \%$ for As, 102.3 to $105.2 \%$ for $\mathrm{Pb}$, and 100.0 to $104.5 \%$ for $\mathrm{Cd}$. The limits of detection and quantification were 0.08 and $0.26 \mu \mathrm{g} \mathrm{g}^{-1}$ for As, 3.77 and $12.6 \mathrm{ng} \mathrm{g}^{-1}$ for $\mathrm{Cd}$, and 0.07 and $0.22 \mathrm{ng} \mathrm{g}^{-1}$ for $\mathrm{Pb}$, respectively. For comparison, a certified reference material (NIST 1568a Rice Flour) was analyzed resulting in a value of $0.28 \pm 0.06 \mu \mathrm{g} \mathrm{g}^{-1}$ for As (certified value of $0.29 \pm 0.03 \mu \mathrm{g}$ $\mathrm{g}^{-1}$ ) and $0.023 \pm 0.001 \mu \mathrm{g} \mathrm{g}^{-1}$ for $\mathrm{Cd}$ (certified value of $0.022 \pm 0.001$ $\left.\mu \mathrm{g} \mathrm{g}^{-1}\right)$. The method offers a simple sample preparation, resulting in adequate accuracy and precision, good sample output, and is very suitable for the quick and cost-effective analysis of potato samples.

the United Nations Food and Agriculture Organization (1) declared 2008 the "International Year of the Potato" to highlight the importance of this food for nutritional security and reduction of hunger.

The potato is the most commonly consumed food, prepared in various forms (fried, boiled, baked, mashed, etc.) and popularly consumed throughout Brazil. According to the Brazilian Ministry of Agriculture (2), Brazil's yearly potato harvest was more than 2.2 million tons in 2013 and cultivated in an area of more than 150000 ha. Most of these fertile lands are situated in the southern
(Paraná and Rio Grande do Sul), southeastern (Minas Gerais and São Paulo) and in smaller proportions, the northeastern (Bahia) states (3). About one-third of the country's potato production comes from Minas Gerais (2).

The country's average per capita consumption is calculated as $13 \mathrm{~kg}$ / year, while Europeans and North Americans consume five times that amount (4). The state of Minas Gerais is also a world iron ore and other mineral exporter, and therefore, due to the impact of intensive cultivation of land and mining activities in this state, there is great concern with regard to the potential contamination of cultivated foods in mining areas. Heavy metals are not biodegrade- or thermodegradeable and readily accumulate to toxic levels (5).

Anthropogenic activities, as is the case for mining in Minas Gerais, in addition to industrial and domestic wastewater, sludge, use of fertilizers and pesticides, are the main sources of heavy metals contamination in plants (6). Thus, it has become increasingly important to evaluate data on potato and other land-intensive farm products. The use of specific methods for monitoring heavy metals in soil and edible plants should become mandatory. These types of data would contribute in the ability to evaluate possible soil and water contamination and their correlation to producing healthy crops.

Heavy metals do not accumulate in all plant parts equally (7). According to several recent publi- 
cations, the highest concentrations of heavy metals are found in roots, with somewhat lower concentrations in stems and leaves, and the lowest in the generative organs and fruits $(8,9)$.

Gichner et al. (10) analyzed the heavy metal content $(\mathrm{Cd}, \mathrm{Cu}, \mathrm{Pb}$, and $\mathrm{Zn}$ ) in tobacco (Nicotian atabacum) and potatoes (Solanum tuberosum) grown in highly polluted and non-polluted soils in Northern Bohemia of the Czech Republic. Sample aliquots $(0.5 \mathrm{~g})$ of air-dried and sieved soil samples were decomposed in borosilicate glass test tubes at $400{ }^{\circ} \mathrm{C}$ for 10 hours in a mixture of oxidizing gases $\left(\mathrm{O}_{2}+\mathrm{O}_{3}+\mathrm{NO}_{\mathrm{X}}\right)$ in a mineralizer. The resultant ash was dissolved in a mixture of $65 \%$ nitric acid and $38 \%$ hydrofluoric acid (2:1), evaporated until dry at $160{ }^{\circ} \mathrm{C}$, then dissolved in $37 \% \mathrm{HCl}$ and $65 \% \mathrm{HNO}_{3}$ (3:1) for measurement. It was also observed that a small but significant increase in DNA damage had occurred in the plants grown in polluted soil versus the controls. The polluted soil probably induced toxic, yet non-genotoxic, effects on the tobacco and potato plants. The Gichner et al. method presents several challenges. It is very time-consuming and expensive since the samples need to be dried in an oven for 10 hours and requires high-purity mixtures of oxidizing gases. In addition, there is the problem of analyte loss during drying and contamination originating from the large amount of reagents used.

Dugo et al. (11) applied potentiometric stripping analysis for the simultaneous determination of $\mathrm{Zn}(\mathrm{II}), \mathrm{Cd}(\mathrm{II}), \mathrm{Pb}(\mathrm{II}), \mathrm{Cu}(\mathrm{II})$, and cathodic stripping potentiometric analysis for measuring the Se concentrations. The metal cations were extracted from the potatoes by hydrogen peroxide/hydrochloric acid treatment. The relative standard deviation of the method ranged from 2.3 to $4.1 \%$, and the detection limits were lower than $2.5 \mu \mathrm{g} \mathrm{kg}^{-1}$. A comparison of the results of their method with those obtained in the proposed method of this study using digestion of the samples and graphite furnace atomic absorption spectrometry (GFAAS) analysis showed a $6.1 \%$ agreement and was considered a good result. Of the four determined metals, $\mathrm{Cu}$ and $\mathrm{Zn}$ were the most abundant with concentrations ranging from 0.5 and $4.6 \mathrm{mg} \mathrm{kg}^{-1}$. Selenium was found in the three samples at very low amounts $\left(<0.1 \mathrm{mg} \mathrm{kg}^{-1}\right)$, while the $\mathrm{Pb}$ and $\mathrm{Cd}$ concentrations ranged from 0.01 to $0.27 \mathrm{mg} \mathrm{kg}^{-1}$. The maximum allowable concentrations (MAC) for $\mathrm{Se}, \mathrm{Pb}$, and $\mathrm{Cd}$ in foodstuffs are 0.05 to $0.2 \mathrm{mg} / \mathrm{kg}$ (12), 0.1 and $0.1 \mathrm{mg} / \mathrm{kg}$ (13), respectively. This method compared with our proposed method is timeconsuming, expensive, and uses higher purity reagents to extract the elements.

Rajkovic et al. (14) determined the heavy metals of $\mathrm{Pb}, \mathrm{Cd}, \mathrm{Ni}, \mathrm{Cr}$, $\mathrm{Mn}, \mathrm{Fe}, \mathrm{Ni}$, and As in potato samples grown in various areas of Serbia with different soils such as in Ivanjica (gray brown skeletoidal soil and flysche), Mrcajevci (alluvial smonitza-meadow soils), Borca (chernozem black soil), Guca (parapodzol pseudogley), Leskovac (marsh black soil), Belegis (chernozem); Rajac (Gornji Milanovac) (shallow back soil buavica on limestone), PKB-Beograd (chernozem); Smederevo (alluvium), Dobanovci (degraded chernozem in the process of browning), and Požarevac (smonitza Novi Pazar). The measurements were performed after acid dissolution of the samples and analysis by flame atomic absorption spectrometry (FAAS). The authors found that potatoes originating from these sites were contaminated with Cd $(>0.005 \mathrm{mg}$ $\mathrm{kg}^{-1}$ ) which exceeds the legal limits by only $0.005 \mathrm{mg} \mathrm{kg}^{-1}$ (15). According to the authors, the high levels of $\mathrm{Cd}$ could be due to the applica- tion of phosphate fertilizers at higher than recommended levels. The principal disadvantage of their method is the use of high amounts of supra-pure acids for sample dissolution.

Rajkovic et al. (14) employed microwave acid digestion of the samples, but presents the same problems as the method proposed by Gichner and colleagues. The acid digestion in an analytical microwave oven requires the acquisition of high cost equipment which has a limited number of vessels. For dissolution of the samples, the procedure must be done at least in duplicate with added blanks and with blanks containing standard metals to investigate possible analyte loss at high temperatures. In addition, there is the possiblity of contamination due to high-cost reagents and the extensive sample manipulation during sample preparation.

Gopalani et al. (16) determined the concentrations of $\mathrm{Zn}, \mathrm{Pb}, \mathrm{Ni}$, $\mathrm{Cd}, \mathrm{Co}, \mathrm{Mg}, \mathrm{Fe}, \mathrm{Cr}, \mathrm{Al}$, and $\mathrm{Cu}$ in potato chips and biscuits obtained in markets of Nagpur City, India. Wet digestion of these samples was performed by adding a mixture of $\mathrm{HNO}_{3}: \mathrm{H}_{2} \mathrm{O}_{2}(8: 4), \mathrm{HNO}_{3}: \mathrm{H}_{2} \mathrm{SO}_{4}(8: 4)$ and $\mathrm{HNO}_{3}: \mathrm{HCl}(8: 4)(12 \mathrm{~mL}$ for a $1.0 \mathrm{~g}$ sample), then heating to 130 ${ }^{\circ} \mathrm{C}$ for 3 hours. After cooling, $5 \mathrm{~mL}$ of distilled water was added, and mixed with distilled water. The residue was filtered through a Whatman filter paper No. 41. The sample was then diluted with 50 $\mathrm{mL}$ of distilled water. Blank digestions were also performed in the same way. The level of analytes in the final solutions was determined by ICP-AES. All sample solutions were run in triplicate and were clear. According to the results, the accumulation of analytes in the potato chips was in the following order: $\mathrm{Fe}>\mathrm{Al}>\mathrm{Zn}>\mathrm{Ni}>\mathrm{Cu}>\mathrm{Mn}>\mathrm{Co}>$ $\mathrm{Cr}>\mathrm{Pb}$ and $\mathrm{Cd}$, while for the biscuits, the results were: $\mathrm{Al}>\mathrm{Fe}>$ $\mathrm{Zn}>\mathrm{Ni}>\mathrm{Mn}>\mathrm{Co}>\mathrm{Cr}>\mathrm{Pb}>\mathrm{Cu}$ and $\mathrm{Cd}$. 
In this method, the authors used 12 $\mathrm{mL}$ of each reagent $\left(\mathrm{HNO}_{3}, \mathrm{H}_{2} \mathrm{SO}_{4}\right.$, $\mathrm{HCl}$ and $\mathrm{H}_{2} \mathrm{O}_{2}$ ), which was of suprapure quality, heated for 3 hours, and then allowed to cool which required more time. Moreover, this can result in the possibility of reagent contamination of the quantified analytes. Finally, the process of residue filtration requires skilled analysts and may result in material loss, and therefore, in determination errors.

Antonius et al. (17) performed heavy metals determination (Cd, $\mathrm{Cr}, \mathrm{Mo}, \mathrm{Cu}, \mathrm{Zn}, \mathrm{Pb}$, and $\mathrm{Ni}$ ) in sweet potato plants (edible roots, leaves, stems, and feeder roots) using inductively coupled plasma mass spectrometry (ICP-MS). In addition, the authors analyzed soil samples for total and extractable metals using two extraction procedures: concentrated nitric acid (to extract total metal from the soil samples) and $\mathrm{CaCl}_{2}$ solution (to extract soluble metals in soil that are available to plants). The authors also analyzed soils and parts of potato plants cultivated in soil treated with MSS (municipal sewage sludge) or YW + MSS (yard waste plus MSS). The total concentrations of $\mathrm{Pb}, \mathrm{Ni}$, and $\mathrm{Cr}$ were greater in plants grown in MSS+YW treatments compared to the control plants. MSS+YW treatments increased the sweet potato yield compared to the control plants. The concentrations of heavy metals in MSS-amended soil and sweet potato roots were below their respective permissible limits (18).

Although the method by Antonious et al. (17) is less susceptible to errors compared to the studies cited for Gichner et al. (10), Dugo et al. (11), Raijovic et al. (14), and Gopalani et al. (16), it also required use of high purity acids and salts for metal extraction, which can result in the contamination from these reagents.
The disadvantages of the methodologies listed above include high cost of reagents and instrumentation, as well as extensive analysis time and possible contamination of the samples. The authors of the present study aimed to develop and validate a method for the determination of $\mathrm{As}, \mathrm{Cd}$, and $\mathrm{Pb}$ in potato samples using a fast and homogeneous sample slurry preparation by introducing air bubbles deep into the autosampler cups containing the potato slurry with a simple and low-cost aquarium pump and optimization of the permanent modifier. Multivariate optimization was used for the pyrolysis and atomization temperatures (factorial design and central composite design), and the analytes (As, $\mathrm{Cd}$, and $\mathrm{Pb}$ ) were determined by graphite furnace atomic absorption spectrometry (GFAAS).

\section{EXPERIMENTAL}

\section{Instrumentation}

In this study, a PerkinElmer ${ }^{\circledR}$ AAnalyst ${ }^{\mathrm{TM}} 400$ atomic absorption spectrometer was used, equipped with an HGA®-800 graphite furnace, background correction with a deuterium lamp, and an AS800 autosampler (PerkinElmer, Inc., Shelton, CT, USA). Readings were made of integrated absorbance (peak area). A PerkinElmer Lumina ${ }^{\circledR}$ hollow cathode lamp (HCL) of $\mathrm{Pb}$ and an electrodeless discharge lamp (EDL) of As and Cd were used, operating under the conditions as recommended by the manufacturer. The GFAAS operat-

TABLE I

Istrumental Operating Parameters for the Determination of As, Cd, and Pb Using the AAnalyst ${ }^{\mathrm{TM}} 400$ GFAAS

\begin{tabular}{llll}
\hline & As & Cd & $\mathrm{Pb}$ \\
\hline Wavelength $(\mathrm{nm})$ & 193.7 & 228.8 & 283.3 \\
Lamp current $(\mathrm{mA})$ and type & $400(\mathrm{EDL})$ & $210(\mathrm{EDL})$ & $10(\mathrm{HCL})$ \\
Slit width $(\mathrm{nm})$ & $2.7 / 2.3$ & $2.1 / 1.35$ & $2.7 / 1.05$ \\
Injected volume into the furnace $(\mu \mathrm{L})$ & 20 & 20 & 20 \\
\hline
\end{tabular}

ing conditions used in these studies are listed in Table I. the inert gas $(99.996 \%$ from White Martins, Belo Horizonte, MG, Brazil). Pyrolytically coated graphite tubes with L'vov platforms (PerkinElmer, Inc.) were used in all studies. Adjustable micropipettes of $20-200 \mu \mathrm{L}$ and $100-1000 \mu \mathrm{L}$ (Digipet, Curitiba, PR, Brazil) were used to prepare the solutions. The samples were ground in a cryogenic Spex 6770 Freezer/Mill@ (Spex SamplePrep, NJ, USA) and thereafter dried in a lyophilizer (Edwards Modulyo 4K, No. F101-01-000, England, UK). During the experiments, a small aquarium aerator pump was also used connected to a capillary tube and immersed in the vial-filled sample.

\section{Reagents, Standard Solutions, and Samples}

The reagents used were of analytical purity. All aqueous solutions were prepared using deionized water $(18.2$ resistivity $\mathrm{M} \Omega \cdot \mathrm{cm})$ obtained with a direct Milli-Q ${ }^{\circledR}$ system (Millipore Corporation, USA). Nitric acid and hydrogen peroxide (Merck, Darmstadt, Germany) were used to prepare the diluent. Treatment of the graphite tubes was done with permanent modifier solutions at a concentration of $1000 \mathrm{mg} \mathrm{L}^{-1}$ using the following elements: ruthenium (Fluka No. 84033), rhodium (Fluka No.83722), iridium (Fluka No.58195), zirconium (Aldrich No.27497-6), niobium (Fluka No.274 917),
High purity argon was used as 
titanium (Aldrich, 03-796 in-1EA), and tantalum (Fluka No.86275), all at $1 \mathrm{~mol} \mathrm{~L}^{-1}$ in hydrochloric acid. At a concentration of $1000 \mathrm{mg} \mathrm{L}^{-1}$, tungsten was also used, prepared by dissolving $0.18 \mathrm{~g}$ of $\mathrm{Na}_{2} \mathrm{WO}_{4}$ (Merck No. 106672) in $100 \mathrm{~mL}$ of deionized water. The analytical solutions of As, $\mathrm{Cd}, \mathrm{Pb}$, and $\mathrm{Ni}$ were obtained from stock solutions of $1000 \mathrm{mg} \mathrm{L}^{-1}$, prepared with 5\% (v/v) nitric acid ampoules (Titrisol ${ }^{\circledR}$, Merck, Germany) and stored according to the manufacturer's instructions.

\section{Treatment of Graphite Tubes with Permanent Modifiers}

Each graphite tube was treated with the tested permanent modifiers (iridium, rhodium, ruthenium, zirconium, tungsten, titanium, tantalum, and niobium), according to Silva et al. (18), and using a specific heating program (Table II). In a graphite tube with L'vov platform, a $50-\mu \mathrm{L}$ volume of each element was injected separately for each element modifier with an automatic pipette. This tube was then submitted to the temperature program and the procedure repeated 10 times to treat the platform with a total of $500 \mu \mathrm{g}$ of the permanent modifier. Each injection procedure of the $50-\mu \mathrm{L}$ element modifier that was inserted into the graphite tube platform required 2 minutes, totaling 20 minutes for the platform treatment process. During this

TABLE II

Temperature Program for Treatment of Graphite Tubes With Permanent Modifiers

\begin{tabular}{rrrrc}
\hline Step & $\begin{array}{c}\text { Temp. } \\
\left({ }^{\circ} \mathrm{C}\right)\end{array}$ & $\begin{array}{c}\text { Ramp } \\
(\mathrm{s})\end{array}$ & $\begin{array}{c}\text { Hold } \\
(\mathrm{s})\end{array}$ & $\begin{array}{c}\text { Ar Flow } \\
\left(\mathrm{mL} \mathrm{min}^{-1}\right)\end{array}$ \\
\hline 1 & 90 & 5 & 15 & 250 \\
2 & 140 & 5 & 15 & 250 \\
3 & 1000 & 10 & 10 & 250 \\
4 & 2000 & 0 & 5 & 0 \\
5 & 20 & 1 & 10 & 250 \\
\hline
\end{tabular}

period, one may prepare the sample slurries.

\section{Samples and Sample Prepara- tion Procedures}

We used potato samples collected in a group of cities popularly referred to as the "Iron Quadrangle" region of Minas Gerais (Mata, Ouro Branco, Brumadinho, Piedade, and Santa Barbara) and other mining regions (Cristalina, Ibiá, Borda da Mata, Bom Repouso, Araxá, Jaíba, and Araújos) (Table III). Three potato samples were obtained from each city, washed with deionized water to remove the soil residue, then dried at room temperature on plastic trays. The skins were removed and all samples grated using a plastic grater decontaminated in acid $\left(\mathrm{HNO}_{3}, 10 \% \mathrm{v} / \mathrm{v}\right)$. Then the samples were transferred to lyophilization flasks and freezedried.

The freeze-dried samples were ground to ensure a satisfactory and uniform particle size in the micrometer range. About $1 \mathrm{~g}$ of the material was placed into a polycarbonate

TABLE III

Coding of Potato Samples Analyzed (n=3)

\begin{tabular}{cl}
\hline Code & City of Origin \\
\hline B1 & Ouro Branco \\
B2 & Brumadinho \\
B3 & Mata \\
B4 & Piedade \\
B5 & Santa Barbara \\
B6 & Jaíba \\
B7 & Cristalina \\
B8 & Ibiá \\
B9 & Borda da Mata \\
B10 & Bom Repouso \\
B11 & Araxá \\
B12 & Araújos \\
\hline
\end{tabular}

tube coupled to a container containing liquid nitrogen. The cryogenic grinding program consisted of three steps of three cycles at a speed of 15 cps (cycles per second) as follows: pre-freezing for $2.0 \mathrm{~min}-$ utes, grinding for 3.0 minutes, and refreezing for 2.0 minutes. After milling, the samples were sieved $(63 \mu \mathrm{m})$ and kept refrigerated in HDPE containers. The slurries of the samples were prepared and injected into the graphite tube. A quantity of $40.0 \mathrm{mg}$ of the sample was weighed directly into each autosampler cup, followed by addition of $2.0 \mathrm{~mL}$ of diluent solution consisting of $2.0 \% \mathrm{HNO}_{3}(\mathrm{v} / \mathrm{v})$ and $1.0 \% \mathrm{H}_{2} \mathrm{O}_{2}(\mathrm{v} / \mathrm{v})$. To maintain the slurries stable, the samples were bubbled using a simple aquarium pump connected to a polyethylene capillary which remained dipped in the vial with the samples during measurement. After taking the homogenized pipetted sample, using the capillary aquarium pump, the pump tube was dipped into another vial containing a 5\% (v/v) nitric acid solution, and then in another vial containing Milli-Q ${ }^{\circledR}$ water, dried with metal-free paper, and dipped into the next vial of another homogenization sample (19).

To evaluate the accuracy in the determination of As and Cd, we analyzed certified reference material NIST 1568a Rice Flour (National Institute of Standards and Technology, USA) as discussed in the Results and Discussion section.

Initially, the drying step was univariate optimized according to the conditions recommended by the manufacturer. Therefore, experiments in which only the drying temperature was changed were carried out until no bubbling was observed in the sample within the graphite furnace. Bubbles lead to sample loss, consequently making the analysis non-reproducible. 


\section{Atomic Apectroscopy 1 Vol. 36(6), Nov./Dec. 2015}

A potato sample was treated and the slurry prepared as described previously. Employing a tube without a modifier and using the conditions recommended by the manufacturer, the absorbance for the analytes was measured to see if the response to those analytes under these conditions would allow for further studies. The first optimization step was to select the most appropriate chemical modifier using the temperature program recommended by the manufacturer. We treated the graphite tubes with different chemical modifiers and chose the two tubes treated with the modifiers that showed the best sensitivity, i.e., greater intensity of the absorbance signal, better correction of "background" absorption pulses, compatible with those usually obtained with this technique, and low relative standard deviations ( $n=3$ replicates). The tubes tested were tubes with platforms treated with the permanent modifiers (tungsten, rhodium, ruthenium, iridium, titanium, tantalum, niobium, and zirconium) and one tube without modifier. In these experiments, we used the time lengths and pyrolysis and atomization temperatures as recommended by the manufacturer. The two modifiers that showed the best results were used to construct a factorial design.
They were chosen randomly for each level (-) and (+) for factorial fier, the pyrolysis and atomization temperatures also required optimization, as the values indicated by the manufacturer refer to analysis in an aqueous medium. Thus, these two parameters were included in the experimental design. Starting from the conditions recommended by the manufacturer, two values were selected for pyrolysis and two for atomization. These values were slightly below and slightly above those recommended. Finally, a $2^{3}$ fractional factorial design was established for preliminary assessment of the variables of pyrolysis temperature, atomization temperature, and chemical modifier. The responses obtained were analyzed using Statistica 6.0 software (provided by Dell, São Caetano do Sul, SP, Brazil) (20).

After determination of the significant parameters, it was possible to observe how each of these parameters affected the response. In the next step, a response surface was obtained from a central composite used to achieve optimum conditions for the analysis. The use of chemical modifier was defined in the factorial design, since this was a qualitative parameter and there was no need of refinement. design. Besides the chemical modi-

\section{RESULTS AND DISCUSSION}

\section{Optimization of Analytical Conditions}

Arsenic did not demonstrate to be a good signal in the initial screening tests of the modifier. Therefore, the sample was spiked with a standard solution of As, resulting in a final concentration of $30 \mu \mathrm{g} \mathrm{L}^{-1}$ which was used for all subsequent optimization steps. With successive tests of drying time and temperature, while maintaining all other conditions constant as recommended by the manufacturer, drying took place with greater efficiency in three stages, ranging from 90 to $200{ }^{\circ} \mathrm{C}$ (Table IV). The best two modifiers selected, together with the pyroslysis and atomization temperature that will compose the factorial design for a first screening of these variables, were then optimized by CCD. The two tubes treated with iridium and ruthenium were selected based on best performance. For these two modifiers, temperatures of 800 and $1400{ }^{\circ} \mathrm{C}$ for pyrolysis and 2000 and $2600{ }^{\circ} \mathrm{C}$ for atomization were considered to build the matrix of the factorial design, as presented in Table $\mathrm{V}$ for arsenic. Table VI shows the integrated absorbance values obtained for the three replicates of this experiment.

TABLE V

TABLE IV

Optimized Furnace Program for the Determination of Inorganic Constituents in Potatoes by GFAAS

\begin{tabular}{lrrrrrr}
\hline Step & \multicolumn{3}{c}{$\begin{array}{c}\text { Temperature } \\
\left({ }^{\circ} \mathrm{C}\right)\end{array}$} & $\begin{array}{c}\text { Ramp } \\
(\mathrm{s})\end{array}$ & $\begin{array}{c}\text { Hold } \\
(\mathrm{s})\end{array}$ & $\begin{array}{c}\text { Ar Flow } \\
\text { Rate } \\
\left(\mathrm{mL} \mathrm{min}^{-1}\right)\end{array}$ \\
\hline Drying & As & $\mathrm{Cd}$ & $\mathrm{Pb}$ & & & \\
Drying & 90 & 90 & 90 & 5 & 10 & 250 \\
Drying & 150 & 150 & 150 & 10 & 20 & 250 \\
Pyrorysis & 200 & 200 & 200 & 10 & 20 & 250 \\
Cool-down & 350 & 800 & 600 & 10 & 20 & 250 \\
Atomization & 2660 & 1600 & 30 & 1 & 5 & 250 \\
Clean & 2700 & 2700 & 2700 & 0 & 5 & 250 \\
\hline
\end{tabular}

Conditions in Factorial Design for the Determination of Each Analyte in Potatoes by GFAAS

\begin{tabular}{ccccc}
\hline Analyte & Level & $\begin{array}{c}\text { Atomization/Pyrolysis } \\
\text { Temperature }\left({ }^{\circ} \mathrm{C}\right)\end{array}$ & Modifier \\
\hline \multirow{2}{*}{ As } & $(-)$ & 2000 & 800 & $\mathrm{Ir}$ \\
& $(+)$ & 2600 & 1400 & $\mathrm{Ru}$ \\
& recommended & 2300 & 1300 & \\
\hline $\mathrm{Cd}$ & $(-)$ & 1600 & 800 & $\mathrm{Zr}$ \\
& $(+)$ & 2100 & 1200 & $\mathrm{Ti}$ \\
& recommended & 1650 & 850 & \\
\hline $\mathrm{Pb}$ & $(-)$ & 1600 & 550 & $\mathrm{Ta}$ \\
& $(+)$ & 2000 & 850 & $\mathrm{Ti}$ \\
& recommended & 1800 & 700 & \\
\hline
\end{tabular}


The results of the Pareto graph (Figure 1) demonstrated that both the pyrolysis and the atomization temperature had a significant effect on the absorbance at a $95 \%$ confidence interval. However, the most intense values were observed for interactions between the modifier and pyrolysis and between the atomization temperatures and modifier. The same graph shows that the best conditions were at $2600{ }^{\circ} \mathrm{C}$ as the atomization temperature and at $800{ }^{\circ} \mathrm{C}$ for the pyrolysis temperature. The modifier had no significant effect, and thus the iridiumtreated tube was chosen for the other tests. In sequence, we used a central composite design (CCD) for a better fit of these two variables for As [atomization temperature (AT) and pyrolysis temperature (PT)] - as shown in Table VI, which is presented in the matrix of experiments using a tube-platform treated with iridium $(500 \mu \mathrm{g})$. Figure 2 shows the surface response obtained by the mathematical treatment of the results obtained with this design. The best pyrolysis and atomization temperatures correspond to the maximum point of the surface, which is the point where the derivative of the surface is zero. Table IV shows the optimized conditions for the furnace heating program for the proposed method for As as well as for $\mathrm{Cd}$ and $\mathrm{Pb}$.

For Cd, the optimization of this method and its validation followed the same sequence as adopted for the As determination. However, it was not necessary to fortify the sample used in the optimization, because it already had an analyte concentration sufficient to generate an absorbance signal suitable for the subsequent experiments required for optimization and validation of the method. The permanent modifiers that produced the best results for this method were zirconium and titanium. These were then chosen for the factorial design of the experiments shown in Table V, with temperatures ranging from 800 to $1200{ }^{\circ} \mathrm{C}$ for pyrolysis and 1600 to $2100{ }^{\circ} \mathrm{C}$ for atomization. The integrated

TABLE VI

Matrix of the Factorial Design Experiments ( $\left.2^{3}\right)$ for Inorganic Constituents in Potato Samples

\begin{tabular}{ccccccc}
\hline $\begin{array}{c}\text { Experi-. } \\
\text { ment }\end{array}$ & AT $^{\mathrm{a}}$ & $\mathrm{PT}^{\mathrm{b}}$ & Mod. $^{\mathrm{c}}$ & \multicolumn{3}{c}{ Integrated Absorbance (s) } \\
\hline 1 & - & - & - & $0.109 \pm 0.010$ & $0.413 \pm 0.019$ & $0.861 \pm 0.069$ \\
2 & + & - & - & $0.033 \pm 0.003$ & $0.158 \pm 0.005$ & $0.711 \pm 0.042$ \\
3 & - & + & - & $0.197 \pm 0.021$ & $0.008 \pm 0.003$ & $0.692 \pm 0.042$ \\
4 & + & + & - & $0.164 \pm 0.005$ & $-0.006 \pm 0.002$ & $0.591 \pm 0.053$ \\
5 & - & - & + & $0.120 \pm 0.006$ & $0.523 \pm 0.021$ & $0.919 \pm 0.015$ \\
6 & + & - & + & $0.249 \pm 0.011$ & $0.223 \pm 0.006$ & $0.784 \pm 0.003$ \\
\hline
\end{tabular}

*Average of three replicates.

${ }^{\mathrm{a}} \mathrm{AT}=$ Atomization Temperature.

${ }^{\mathrm{b}} \mathrm{PT}=$ Pyrolysis Temperature.

${ }^{c}=$ Modifier

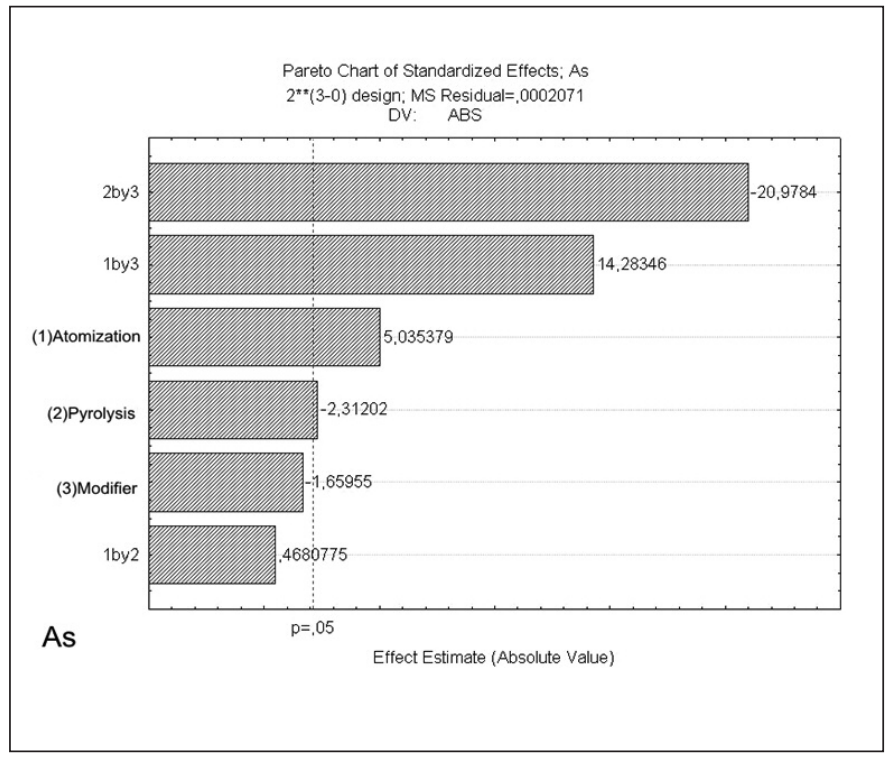

Fig. 1. Pareto chart generated in the factorial design $\left(2^{3}\right)$ for arsenic in potatoes.

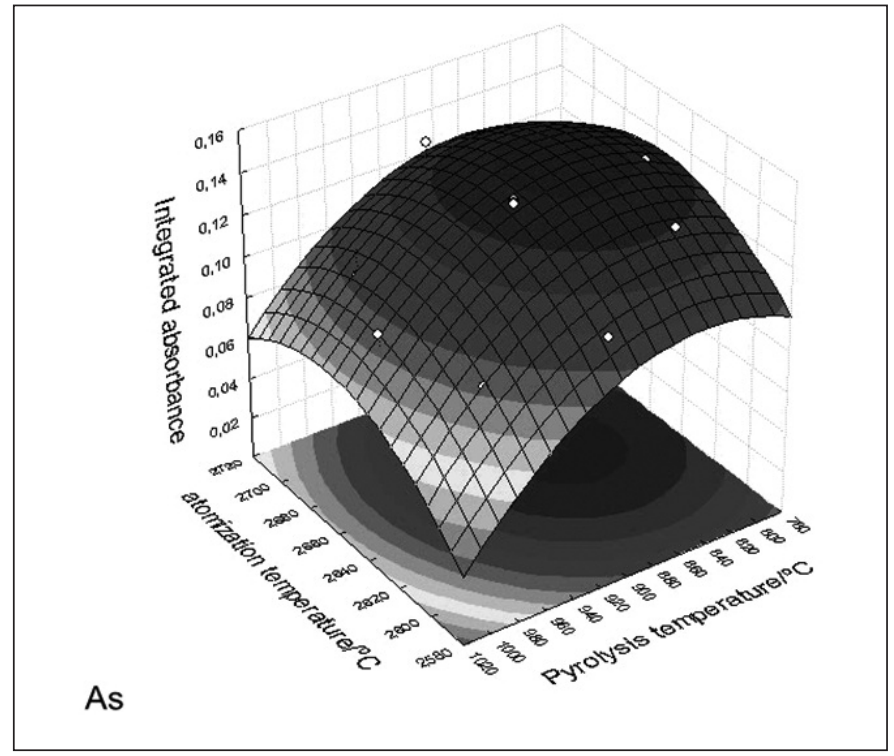

Fig. 2. Response surface obtained from the CCD to arsenic in potatoes. 
absorbance values presented in Table VI correspond to the average measurements of three replicates.

From the generated Pareto graph (Figure 3) it can be seen that all three factors and the interactions between them showed significant effects on the absorbance at a $95 \%$ confidence interval. The same graph shows that the best conditions for atomization were at temperatures between $1600{ }^{\circ} \mathrm{C}$ and $800{ }^{\circ} \mathrm{C}$ for pyrolysis. The $\mathrm{CCD}$ was then constructed from these two temperature values. The best modifier was titanium. This tube was used in the CCD experiments as outlined in Table VII. Figure 4 shows the surface response obtained with this design. Table IV lists the heating program used for the proposed determination after optimization.

The optimization and validation of the method for $\mathrm{Pb}$ followed the same sequences as for As and Cd presented above. The sample used in this step was fortified with $\mathrm{Pb}$ to a final concentration of $30 \mu \mathrm{g} \mathrm{L}^{-1}$.

In the tests to select the two permanent modifiers for the factorial design using the pyrolysis and atomization temperature and time recommended by the manufacturer, tantalum and titanium performed best (Table V). In addition to these two modifiers, we also considered temperature ranges of 550 to 850

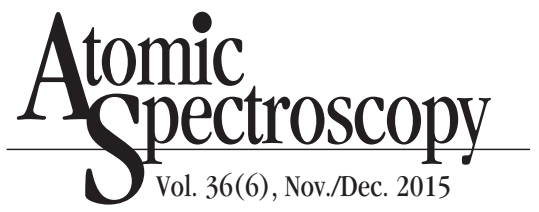

${ }^{\circ} \mathrm{C}$ for pyrolysis and 1600 to 2000

${ }^{\circ} \mathrm{C}$ for atomization. Tables V and VI show the matrices of the factorial design and their results. Table VIII presents the CCD array and Figures 5 and 6 illustrate the Pareto graph

TABLE VII

Matrix of Central Composite Design (CCD) Experiments for As and Cd in Potato Samples

\begin{tabular}{ccrc|cccc}
\hline & \multicolumn{3}{c|}{ As } & & & $\mathrm{Cd}$ & \\
\hline Exp. $^{\mathrm{a}}$ & $\begin{array}{r}\mathrm{TA}^{\mathrm{b}} \\
\left({ }^{\circ} \mathrm{C}\right)\end{array}$ & $\begin{array}{c}\mathrm{TP}^{\mathrm{c}} \\
\left({ }^{\circ} \mathrm{C}\right)\end{array}$ & $\begin{array}{c}\text { Integr. Abs. } \\
(\mathrm{s})\end{array}$ & Exp. $^{\mathrm{a}}{ }^{\mathrm{C}}$ & $\begin{array}{c}\mathrm{TA}^{\mathrm{b}} \\
\left({ }^{\circ} \mathrm{C}\right)\end{array}$ & $\begin{array}{l}\mathrm{TP}^{\mathrm{c}} \\
\left({ }^{\circ} \mathrm{C}\right)\end{array}$ & $\begin{array}{c}\text { Integr. Abs. } \\
(\mathrm{s})\end{array}$ \\
\hline 1 & 2610 & 830 & 0.133 & 1 & 1530 & 700 & 0.576 \\
2 & 2610 & 970 & 0.092 & 2 & 1530 & 900 & 0.639 \\
3 & 2690 & 830 & 0.133 & 3 & 1770 & 700 & 0.474 \\
4 & 2690 & 970 & 0.097 & 4 & 1770 & 900 & 0.449 \\
5 & 2600 & 900 & 0.108 & 5 & 1480 & 800 & 0.717 \\
6 & 2700 & 900 & 0.136 & 6 & 1820 & 800 & 0.505 \\
7 & 2650 & 800 & 0.136 & 7 & 1650 & 660 & 0.633 \\
8 & 2650 & 1000 & 0.099 & 8 & 1650 & 940 & 0.628 \\
PC & 2650 & 900 & 0.138 & PC & 1650 & 800 & 0.764 \\
PC & 2650 & 900 & 0.137 & PC & 1650 & 800 & 0.752 \\
PC & 2650 & 900 & 0.139 & PC & 1650 & 800 & 0.774 \\
PC & 2650 & 900 & 0.133 & PC & 1650 & 800 & 0.769 \\
PC & 2650 & 900 & 0.134 & PC & 1650 & 800 & 0.738 \\
\hline
\end{tabular}

${ }^{\mathrm{a}}$ Exp. $=$ Experiment

b TA - Atomization temperature.

${ }^{c} \mathrm{TP}=$ Pyrolysis temperature.

${ }^{\mathrm{d}}$ Integr. Abs. = integrated Absorbance.

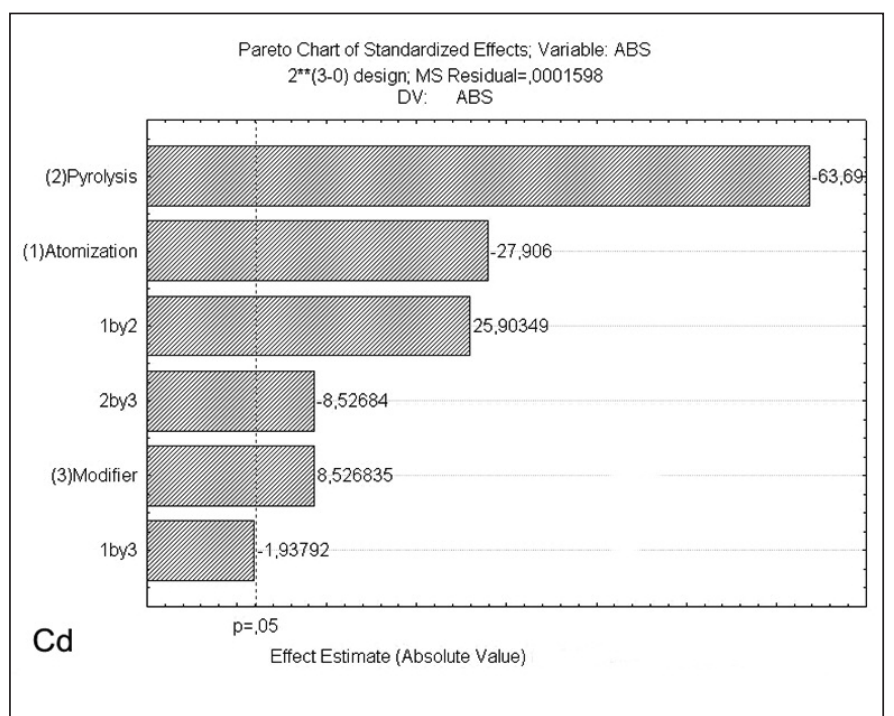

Fig. 3. Pareto chart generated in the factorial design $\left(2^{3}\right)$ for cadmium in potatoes.

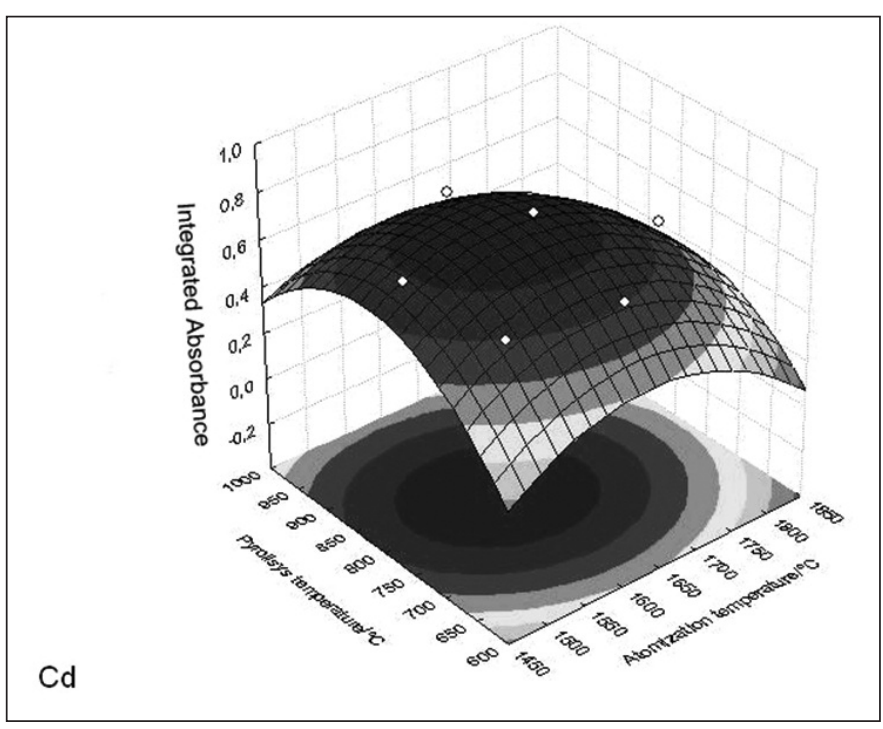

Fig. 4. Response surface obtained from the CCD for cadmium in potatoes. 
and surface response generated by CCD, respectively, obtained at this stage of optimization.

From the Pareto chart (Figure 5), we observed that the three studied factors had a significant effect on the absorbance at a 95\% confidence interval including all interactions, except between the pyrolysis temperature and modifier. The best atomization temperature was 1600 ${ }^{\circ} \mathrm{C}$, and the best pyrolysis temperature was $550{ }^{\circ} \mathrm{C}$. These two values were considered for the preparation of the CCD. The best permanent modifier was titanium; therefore, the tube treated with this metal was used in the following tests. The statistical processing of these results found in the CDD obtained a surface response as shown in Figure 6. The optimized conditions for the heating program of the graphite furnace for the determination of $\mathrm{Pb}$ in the potato samples are presented in Table IV.

\section{Analytical Figures of Merit}

Figure 7 presents the mean values obtained for the three calibrated curves using aqueous stan-
TABLE VIII

Matrix of Central Composite Design (CCD) Experiments for $\mathrm{Pb}$ in Potato Samples

\begin{tabular}{cccc}
\hline Exp. & $\begin{array}{r}\text { TA }^{\mathrm{b}} \\
\left({ }^{\circ} \mathrm{C}\right)\end{array}$ & $\begin{array}{c}\mathrm{TP}^{\mathrm{c}} \\
\left({ }^{\circ} \mathrm{C}\right)\end{array}$ & $\begin{array}{c}\text { Int.Abs. } \\
(\mathrm{s})\end{array}$ \\
\hline 1 & 1400 & 600 & 0.509 \\
2 & 1400 & 900 & 0.495 \\
3 & 1700 & 600 & 0.329 \\
4 & 1700 & 900 & 0.335 \\
5 & 1340 & 750 & 0.486 \\
6 & 1760 & 750 & 0.282 \\
7 & 1550 & 540 & 0.455 \\
8 & 1550 & 960 & 0.430 \\
PC & 1550 & 750 & 0.524 \\
PC & 1550 & 750 & 0.522 \\
PC & 1550 & 750 & 0.523 \\
PC & 1550 & 750 & 0.522 \\
PC & 1550 & 750 & 0.519 \\
\hline
\end{tabular}

${ }^{\mathrm{a}}$ Exp. $=$ Experiment

b $\mathrm{TA}=$ Atomization Temperature.

c $\mathrm{TP}=$ Pyrolysis Temperature .

${ }^{\mathrm{d}}$ Int. Abs.= Integrateed Absorbance. dards (aqueous calibration curves) and for three curves performed with the matrix (matrix-matched calibration curves) obtained for As. The dashed line curve corresponds to that constructed in aqueous solution (aqueous calibration curve) and the solid line curve corresponds to that of the standard additions to the sample (matrix-matched calibration curve). As can be deduced visually, there is a very significant difference between the slopes of the curves, thus eliminating the need for statistical tests (F-test and Student's $t$-test) to conclude that there was a matrix effect. The method demonstrated satisfactory linearity since the correlation coefficient of the calibration curve was greater than 0.99 for the studied range. In the following studies for As, matrix-matched calibration curves were always used in the working range to 5.2 to $60.0 \mu \mathrm{g} \mathrm{L}^{-1}$ (Table IX).

Other figures of merit determined by this method are listed in Table IX. The characteristic mass determined for As is close to the value recommended by the equipment manu-

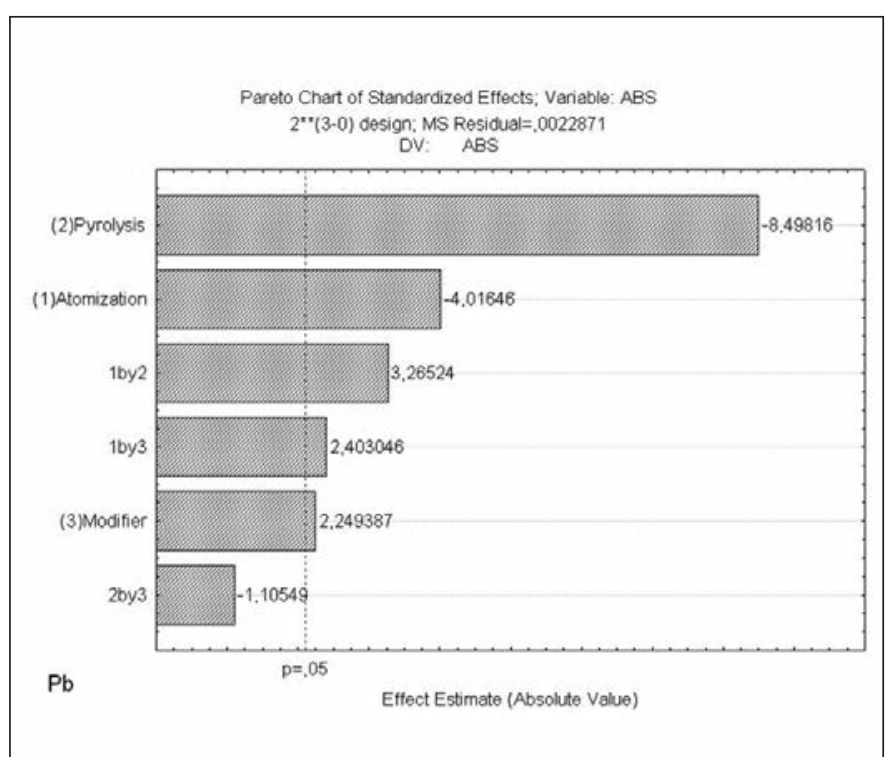

Fig. 5. Pareto chart generated in the factorial design $\left(2^{3}\right)$ for lead in potatoes.

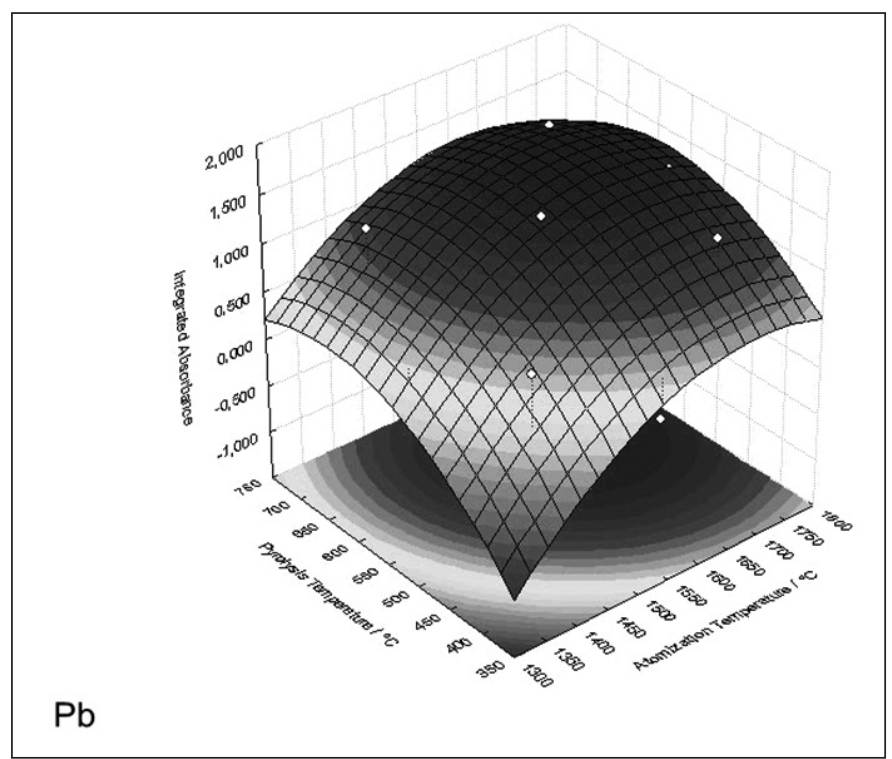

Fig. 6. Response surface obtained from the CCD for lead in potatoes. 


\section{Atomic Spectroscopy \\ 1 Vol. 36(6), Nov./Dec. 2015}

facturer. The results obtained for the limits of detection and quantification were suitable for the determination of As by GFAAS and compatible with other methods found in the literature. In the simultaneous determination of some analytes in wine with the direct introduction of the sample, Ajtony et al. (21) proposed a method in which the LOD was $2.0 \mu \mathrm{g} \mathrm{L}^{-1}$ of As. Comparing GFAAS and HGAAS, Shah et al. (22) proposed a GFAAS method developed for the determination of As in chicken meat which showed an LOQ of $0.18 \mu \mathrm{g} \mathrm{g}^{-1}$.

Table $\mathrm{X}$ presents the results obtained for precision (intra- and inter-assay) using the method proposed in this paper, i.e., for seven aliquots of the same sample: three quantities of As were added to obtain concentrations within the calibration range. The readings were performed in triplicate. This analysis allowed obtaining coefficients of variation (CVs) for the intra-assay and recovery studies of the added metal. This analysis was repeated in the same way with the other aliquots of the same sample on three consecutive days to obtain the inter-assay $\mathrm{CV}$ and the percentage recovery. The $\mathrm{CV}$ results ranged from 4.6 to $6.6 \%$ for intra-assay precision and 3.9 to $7.5 \%$ for interassay precision. These values were in the acceptable limits for the ranges chosen for testing (23).

Figure 8 presents the average $(n=3)$ of the two calibration curves for Cd (the aqueous and matrixmatching calibration curves). The method showed satisfactory linearity and both calibration curves had a correlation coefficient greater than 0.99 for the studied range (0.25 to $\left.5.0 \mu \mathrm{g} \mathrm{L}^{-1}\right)$. The statistical tests used (F-test and Student's $t$-test) resulted in a non-statistical difference between the slopes of the curves. The aqueous calibration curve was used for the recovery tests.

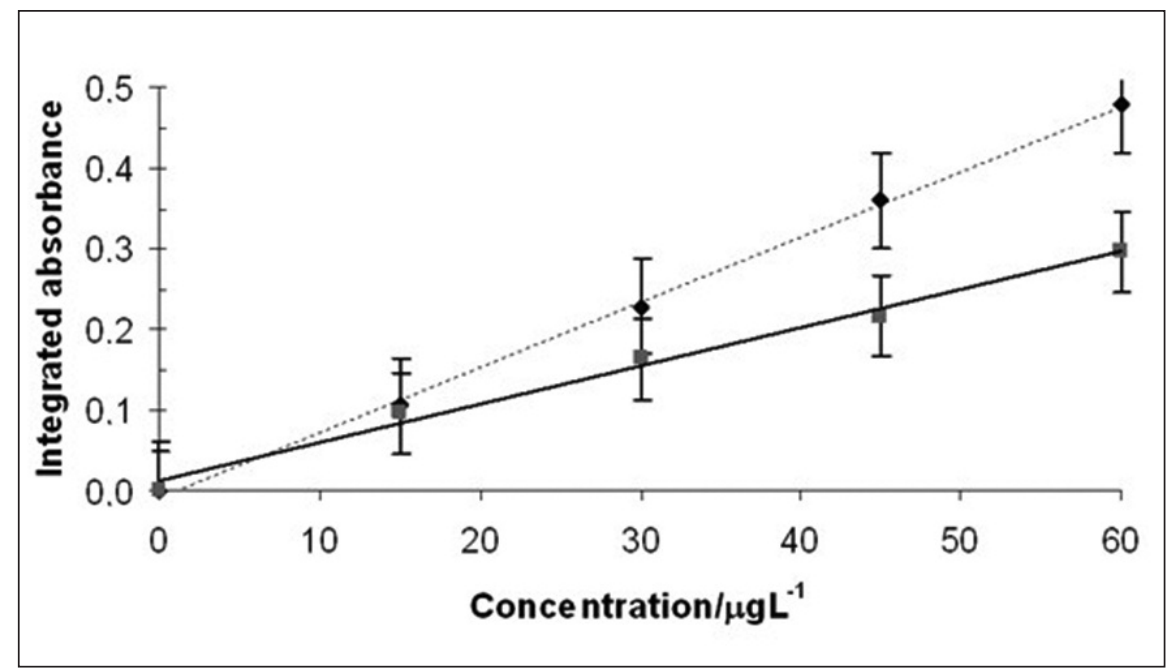

Fig. 7. Matrix effect to determine As in potatoes. The dashed line represents the mean for the three calibration curves for matrix matching calibration. The solid line represents the mean for the three aqueous calibration curves.

TABLE IX

Analytical Figures of Merit in the Determination of $\mathrm{As}, \mathrm{Cd}$, and $\mathrm{Pb}$ in Potatoes

\begin{tabular}{|c|c|c|c|}
\hline Parameters & \multicolumn{3}{|l|}{ Results } \\
\hline \multirow[t]{3}{*}{ Regression equations $(n=3)$} & \multicolumn{3}{|c|}{$\mathrm{Abs}=(0.0052 \pm 0.0011) \mathrm{CAs}+(0.0110 \pm 0.010)$} \\
\hline & \multicolumn{3}{|c|}{$\mathrm{Abs}=(0.2745 \pm 0.0292) \mathrm{CCd}+(0.0455 \pm .0087)$} \\
\hline & \multicolumn{3}{|c|}{$\mathrm{Abs}=(0.0074 \pm 0.0005) \mathrm{CPb}+(0.054 \pm 0.029)$} \\
\hline Analyte & As & $\mathrm{Cd}$ & $\mathrm{Pb}$ \\
\hline$R^{2}(n=3)$ & $\begin{array}{l}0.9956 \pm \\
0.0009\end{array}$ & $\begin{array}{l}0.9971 \pm \\
0.0013\end{array}$ & $\begin{array}{l}0.9992 \pm \\
0.0010\end{array}$ \\
\hline Linear working range & $5.2-60.0$ & $0.25-5.0$ & $4.0-50.0$ \\
\hline $\operatorname{LOD}\left(\mu \mathrm{gL}^{-1}\right)$ & 1.36 & 0.08 & 1.32 \\
\hline$\left(\mu g g^{-1}\right)$ & 0.08 & 3.77 & 0.07 \\
\hline $\operatorname{LOQ}\left(\mu \mathrm{g} \mathrm{L}^{-1}\right)$ & 5.15 & 0.25 & 4.39 \\
\hline$\left(\mu \mathrm{g} \mathrm{g}^{-1}\right)$ & 0.26 & 0.013 & 0.22 \\
\hline Characteristic mass $(\mathrm{pg})^{\mathrm{a}}$ & $15.8 \pm 2.8$ & $0.28 \pm 0.04$ & $11.0 \pm 0.4$ \\
\hline Recovery (\%) & $97.4-102.8$ & $100.0-104.5$ & $102.3-105.2$ \\
\hline Intra-assay precision $(n=5)$ & $4.6-6.6$ & $6.0-8.9$ & $3.5-6.4$ \\
\hline Inter-assay precision $(n=15)$ & $3.9-7.5$ & $6.0-6.8$ & $4.8-6.8$ \\
\hline
\end{tabular}

${ }^{\mathrm{a}}$ Recommended characteristic mass $=20 \mathrm{pg}$ for $\mathrm{As}, 0.5 \mathrm{pg}$ for $\mathrm{Cd}$, and $10 \mathrm{pg}$ for $\mathrm{Pb}$.

Table IX shows the other figures of merit for Cd determined with the proposed study method. The determined characteristic mass is close to the value recommended by the equipment manufacturer. For the LOD and LOQ, the values were also suitable for determination by 
GFAAS and compatible with other methods as found in the literature. Aranda et al. (24), using cloud point extraction in biological samples, digested by microwave oven, reported a method in which the LOQ was $0.27 \mu \mathrm{g} \mathrm{L}^{-1}$. In yet another study, Alexio et al. (25) obtained an LOQ of $0.3 \mu \mathrm{g} \mathrm{L}^{-1}$ for the determination of $\mathrm{Cd}$ in various foods, such as eggplant and mushrooms. Bobrowska-Grzesik (26), analyzing dried fruits and herbs, obtained LOD and LOQ values equal to 0.34 $\mu \mathrm{g} \mathrm{L}^{-1}$ and $1.10 \mu \mathrm{g} \mathrm{L}^{-1}$, respectively, by the method employed.

Table $\mathrm{X}$ lists the results obtained in the CV studies for the intra- and inter-assay precision. The studies with Cd were conducted similarly to those with As. The CV ranged from 6.0 to $7.9 \%$ for intra-assay precision and 6.0 to $6.8 \%$ for interassay precision within the limits acceptable for the range chosen for the tests (23).

The average calibration curves ( $\mathrm{n}=3$ for each kind of curve) for $\mathrm{Pb}$ are shown in Figure 9. The method presents satisfactory linearity and both calibration curves showed a correlation coefficient greater than 0.99 for the studied range (4.0 to $\left.50.0 \mathrm{mg} \mathrm{L}^{-1}\right)$. The F-test and the Student's $t$-test were applied to compare the slopes of the curves. The results indicated no significant difference between the slopes of the external and matrix-matched calibration curves; therefore, all other analyses were performed employing external calibration (aqueous standards).

The other figures of merit determined in this study for $\mathrm{Pb}$ are presented in Table IX. The characteristic mass determined was slightly lower than that recommended by the equipment manufacturer for water, indicating good sensitivity of the proposed method for $\mathrm{Pb}$ determination. The LOD and LOQ values obtained were also suitable for analysis by GFAAS and compatible with other methods found in the literature. Kalny et al. (27), for example, used the GFAAS technique and proposed a method for the determination of trace elements (Ba, Cd, Cr, Cu, Fe, Ni, $\mathrm{Pb}$, and $\mathrm{Zn}$ ) in herbs and their infusions resulting in an LOQ of $0.21 \mu \mathrm{g} \mathrm{g}^{-1}$. Kilic et al. (28) determined $\mathrm{Pb}$ in chewing gum produced in Turkey using ETAAS. Their method presented an LOD equal to $1.2 \mu \mathrm{g} \mathrm{L} \mathrm{L}^{-1}$. Dessuy et al. (29) developed a method for the determination of $\mathrm{Pb}$ in wine, where the LOQ was $1.8 \mu \mathrm{L}^{-1}$.

Table $\mathrm{X}$ presents the results obtained for the intra- and interassay $\mathrm{CV}$ for $\mathrm{Pb}$ in the same way as was done for As and Cd. The CV values for $\mathrm{Pb}$ were between 3.5 and $6.4 \%$ for intra-assay precision, and 4.8 to $6.8 \%$ for inter-assay precision. Both cases were within the limits proposed in the literature (23).

\begin{tabular}{|c|c|c|}
\hline $\begin{array}{l}\text { Concen- } \\
\text { tration } \\
\left(\mu \mathrm{g} \mathrm{L}^{-1}\right)\end{array}$ & $\begin{array}{c}\text { CV intra- } \\
\text { assay } \\
(\%, n=5)\end{array}$ & $\begin{array}{l}\text { CV inter- } \\
\text { assay } \\
(\%, n=15)\end{array}$ \\
\hline \multicolumn{3}{|l|}{ As } \\
\hline 10.0 & $4.6 \pm 2.3$ & $7.5 \pm 2.1$ \\
\hline 20.0 & $6.6 \pm 1.4$ & $3.9 \pm 1.3$ \\
\hline 50.0 & $4.8 \pm 0.7$ & $4.5 \pm 0.8$ \\
\hline \multicolumn{3}{|l|}{$\mathrm{Cd}$} \\
\hline 0.8 & $6.0 \pm 1.8$ & $6.1 \pm 2.3$ \\
\hline 2.0 & $6.1 \pm 2.4$ & $6.8 \pm 1.8$ \\
\hline 4.0 & $7.9 \pm 1.6$ & $6.0 \pm 3.4$ \\
\hline \multicolumn{3}{|l|}{$\mathrm{Pb}$} \\
\hline 10.0 & $4.0 \pm 0.8$ & $6.8 \pm 2.5$ \\
\hline 20.0 & $6.4 \pm 2.2$ & $6.6 \pm 2.6$ \\
\hline 40.0 & $3.5 \pm 1.6$ & $4.8 \pm 2.2$ \\
\hline
\end{tabular}

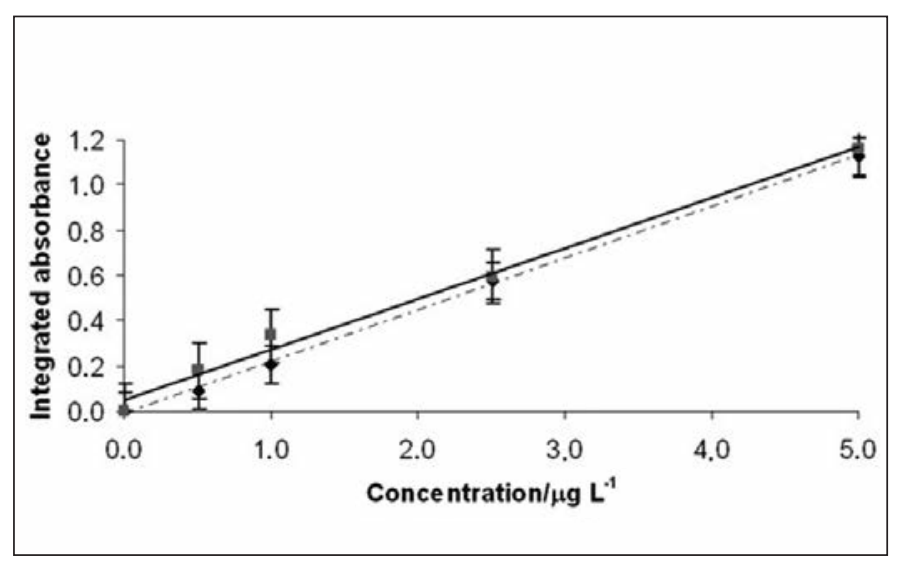

Fig. 8. Matrix effect to determine Cd in potatoes. The dashed line represents the mean for the three calibration curves for matrix matching calibration, while the solid line represents the mean for the three aqueous calibration curves.

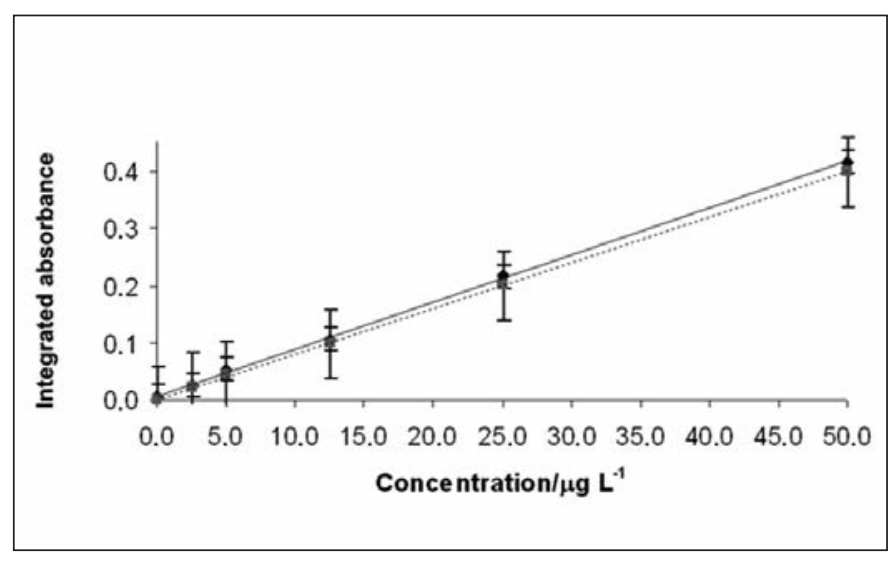

Fig. 9. Matrix effect to determine Pb in potatoes. The dashed line represents the mean for the three calibration curves for matrix matching calibration, while the solid line represents the mean for the three aqueous calibration curves. 


\section{Accuracy}

Table XI presents the results of the recovery tests for $\mathrm{As}, \mathrm{Cd}$, and $\mathrm{Pb}$ after spiking the samples at three different concentrations. From these results we conclude that the analyte recoveries were quite adequate, being within the range proposed in the literature, which is $80-120 \%$ (30). The result of total As for the certified reference material NIST 1568 a Rice Flour $(0.29 \pm 0.03) \mu \mathrm{g} \mathrm{g}^{-1}$ using the proposed method was $0.28 \pm 0.06 \mu \mathrm{g} \mathrm{g}^{-1}$. The F-test and $t$-test indicated no difference between these values with a 95\% confidence interval. For Cd, even with a very low concentration of the certified value in this reference material $\left(0.022 \pm 0.002 \mu \mathrm{g} \mathrm{g}^{-1}\right)$, the mean values of $0.023 \pm 0.001 \mu \mathrm{g} \mathrm{g}^{-1}$ were also not different, as shown according to the two statistical tests. This demonstrates good accuracy of the proposed method.

\section{Analytical Application}

Table XII lists the levels of As, $\mathrm{Cd}$, and $\mathrm{Pb}$ in potatoes collected from the Iron Quadrangle and other mining regions. It was observed that the As concentration range found for these samples was from $<$ LOD $0.08 \mu \mathrm{g} \mathrm{g}^{-1}$ to $0.177 \mu \mathrm{g} \mathrm{L}^{-1}$. All results are below the LOQ $(0.26$ $\mu \mathrm{g} \mathrm{g}^{-1}$ ), except for samples B1 and $\mathrm{B} 2$, which showed values between the LOD and LOQ. The Cd concentrations in the same samples were from 19.5 to $80.4 \mu \mathrm{g} \mathrm{g}^{1}{ }^{1}$. The $\mathrm{Pb}$ concentrations ranged from $<$ LOD $0.07 \mathrm{ng} \mathrm{g}^{-1}$ to $0.666 \mu \mathrm{g} \mathrm{g}^{-1}$. These metal levels were below the MAC values as stipulated by WHO (12). The provisional tolerable weekly intake (PTWI) limits (according to WHO safety standards) (31) for the investigated constituents were $15 \mu \mathrm{g} \mathrm{kg}^{-1}$ for As, $2.5 \mu \mathrm{g} \mathrm{kg}-1$ for $\mathrm{Cd}$, and $50 \mu \mathrm{g} \mathrm{kg}^{-1}$ for $\mathrm{Pb}$ for average consumption of potatoes. Our studies are in accordance with the findings of an ongoing monitoring program which has revealed the occurrence of high concentrations of $\mathrm{Pb}$ in surface waters from the Iron Quadrangle region of Minas Gerais, Brazil (32).

\section{TABLE XI}

Recoveries of $\mathrm{As}, \mathrm{Cd}$, and $\mathrm{Pb}$ From Spiked Potato Samples by GFAAS

\begin{tabular}{|c|c|c|c|}
\hline & $\begin{array}{c}\text { Concentration } \\
\left(\mu \mathrm{g} \mathrm{L}^{-1}\right)\end{array}$ & $\begin{array}{c}\text { Determined } \\
\left(\mu \mathrm{g} \mathrm{L}^{-1}, \mathrm{n}=15\right)\end{array}$ & $\begin{array}{l}\text { Recovery } \\
(\%)(n=15)\end{array}$ \\
\hline \multicolumn{4}{|l|}{ As } \\
\hline & 10.0 & $10.1 \pm 1.5$ & $101.0 \pm 15.4$ \\
\hline & 20.0 & $19.5 \pm 2.0$ & $97.4 \pm 10.0$ \\
\hline & 50.0 & $51.4 \pm 2.9$ & $102.8 \pm 7.4$ \\
\hline \multicolumn{4}{|c|}{$\mathrm{Cd}$} \\
\hline & 0.75 & $0.75 \pm 0.03$ & $100.0 \pm 3.5 \%$ \\
\hline & 2.0 & $2.09 \pm 0.06$ & $104.5 \pm 3.2 \%$ \\
\hline & 4.0 & $4.07 \pm 0.20$ & $101.7 \pm 4.9 \%$ \\
\hline \multicolumn{4}{|c|}{$\mathrm{Pb}$} \\
\hline & 10.0 & $10.2 \pm 0.5$ & $102.3 \pm 4.6$ \\
\hline & 20.0 & $20.6 \pm 1.4$ & $103.2 \pm 6.8$ \\
\hline & 40.0 & $42.1 \pm 2.1$ & $105.2 \pm 0.1$ \\
\hline
\end{tabular}

\section{Atomic Apectroscopy \\ Vol. 36(6), Nov./Dec. 2015}

\section{CONCLUSION}

Based on the analyses carried out in this work, we can conclude that the direct determination (without previous digestion of the samples) of arsenic, cadmium, and lead in potato samples is possible. The results show good sensitivity with $\mathrm{mo}_{\mathrm{s}}$ of $15.8 \mathrm{pg}, 0.28 \mathrm{pg}$, and $11.0 \mathrm{pg}$ for $\mathrm{As}, \mathrm{Cd}$, and $\mathrm{Pb}$, respectively (recommended characteristic mass $=20 \mathrm{pg}$ for As, $0.5 \mathrm{pg}$ for $\mathrm{Cd}$, and $10 \mathrm{pg}$ for $\mathrm{Pb}$ ). The accuracy result for the certified values was $0.29 \mu \mathrm{g}$ $\mathrm{g}^{-1}$ for As and the obtained value was $0.28 \mu \mathrm{g} \mathrm{g}^{-1}$ for Cd. Yjr CV interassay precision obtained was $<7.5 \%$ for As, and $<6.8 \%$ for $\mathrm{Cd}$ and $\mathrm{Pb}$. Optimization of the analytical conditions using chemometric statistical methods was a simple and rapid procedure to obtain the desired sensitivity, precision, and accuracy.

The calibration in all cases, employing matrix-matched calibration for As or aqueous calibration for $\mathrm{Cd}$ and $\mathrm{Pb}$, showed acceptable correlation coefficients $(0.9956$, 0.9971 , and 0.9992 for As, Cd, and

TABLE XII

Average Levels ( $\mathrm{n}=3$ ) of $\mathrm{As}, \mathrm{Cd}$, and $\mathrm{Pb}$ Obtained From Potato Samples Using the Proposed Methods

\begin{tabular}{cccc}
\hline Sample & $\begin{array}{c}\text { As Levels } \\
\left(\mu \mathrm{g} \mathrm{g}^{-1}\right)\end{array}$ & $\begin{array}{c}\text { Cd Levels } \\
\left(\mathrm{ng} \mathrm{g}^{-1}\right)\end{array}$ & $\begin{array}{c}\text { Pb Levels } \\
\left(\mu \mathrm{g} \mathrm{g}^{-1}\right)\end{array}$ \\
\hline B1 & $0.177 \pm 0.036$ & $80.4 \pm 4.46$ & $0.168 \pm 0.003$ \\
B2 & $0.135 \pm 0.049$ & $79.0 \pm 0.50$ & $0.469 \pm 0.010$ \\
B3 & $<$ LOD & $23.6 \pm 1.29$ & $0.274 \pm 0.015$ \\
B4 & $<$ LOD & $21.5 \pm 0.57$ & $0.479 \pm 0.012$ \\
B5 & $<$ LOD & $20.5 \pm 0.58$ & $0.361 \pm 0.031$ \\
B6 & $<$ LOD & $23.5 \pm 0.94$ & $0.580 \pm 0.009$ \\
B7 & $<$ LOD & $23.8 \pm 0.50$ & $0.634 \pm 0.009$ \\
B8 & $<$ LOD & $32.0 \pm 1.14$ & $0.588 \pm 0.028$ \\
B9 & $<$ LOD & $22.7 \pm 1.04$ & $0.353 \pm 0.034$ \\
B10 & $<$ LOD & $26.8 \pm 1.09$ & $<$ LOD \\
B11 & $<$ LOD & $19.5 \pm 1.17$ & $0.666 \pm 0.025$ \\
\hline
\end{tabular}

LOD: As $=0.08 \mu \mathrm{g} \mathrm{g}^{-1} ; \mathrm{Pb}=0.07 \mu \mathrm{g} \mathrm{g}^{-1}$. 
$\mathrm{Pb}$, respectively). The tests with the certified material (NIST 1568 Rice Flour) were in agreement (for As and (d) between the certified and determined values and with compatible standard deviations. The provisional tolerable weekly intake (PTWI) limits (according to WHO safety standards) for the investigated constituents are $15 \mu \mathrm{g}$ $\mathrm{kg}^{-1} \mathrm{As}, 2.5 \mu \mathrm{g} \mathrm{kg}{ }^{-1} \mathrm{Cd}$, and $50 \mu \mathrm{g} \mathrm{kg}$ $\mathrm{Pb}$ based on average consumption of potatoes.

For this study, the concentration of As was within 3\% of the PTWI limits, while the level of Cd was within $10 \%$, and the $\mathrm{Pb}$ level was between 1 and 3\%. The $\mathrm{Pb}$ concentrations thus obtained show that there is a risk to public health. These results also confirm the findings of an ongoing monitoring program which has revealed the occurrence of high concentrations of $\mathrm{Pb}$ in surface waters from the Iron Quadrangle region of Minas Gerais, Brazil.

\section{ACKNOWLEDGMENT}

The authors are grateful for the financial support of the Conselho Nacional de Pesquisa e Desenvolvimento $(\mathrm{CNPq})$ and the Fundação de Amparo à Pesquisa do Estado de Minas Gerais (FAPEMIG). J.B.B. Silva was a scholarship beneficiary from CNPq.

Received July 3, 2015.

\section{REFERENCES}

1. FAO, Food and Agriculural Organization, United Nations, USA, International Year of the Potato (2008). Retrieved July 29, 2012 from: www.potato2008.org.

2. IBGE - Instituto Brasileiro de Geografia e Estatística, (2013) Levantamento Sistemático da Produção Agrícola (LSPA - Jan. 2013). Retrieved March 2, 2013, from http://www.ibge.gov.br/ home/estatistica/indicadores/agro
pecuaria/lspa/estProdAgr_201301. pdf.

3. MAPA - Ministério da Agricultura Pecuária e Abastecimento, (2012). Retrieved July 10, 2012, from: http://www.agricultura.gov.br/.

4. http://ec.europa.eu/agriculture/ publi/reports/fruitveg/potato/sec5 33_en.pdf (Accessed September 1, 2015).

5. R.K. Sharma, M. Agrawal, and F. Marsha, Ecotoxicol. and Environm. Safety 66, 258 (2007).

6. M. Muchuweti, J.W. Birkett, E. Chinyanga, R. Zvauya, and M.D. Scrimshaw, and J.N. Lester, Agriculture, Ecosyst. And Environm. 112, 41 (2006).

7. S. Stasinos and I. Zabetakis, Ecotoxicol. and Environm. Safety 91, 122 (2013).

8. S. Gupta, S. Satpati, S. Nayek, and D. Garai, Environm. Monitoring and Assessmt. 165, 169 (2010).

9. E. Islam, X.E. Yang, Z.L. He, and Q. Mahmood, J. of Zhejiang University-Science B, 8, 1 (2007).

10. T. Gichner, Z. Patková, J. Szakova, and K. Demnerova, Ecotoxicol. Environm. Safety 65, 420 (2006).

11. G. Dugo, L. La Pera, V .Lo Turco, D. Giuffrida, and S. Restuccia, Food Add. Contam. 21, 649 (2004).

12. Maximum Allowable Concentrations. Northwest Territories Drinking Water Quality Database. Chemical, Physical and Biological Parameters. Retrieved September 03, 2015 from:

http://www.maca.gov.nt.ca/operat ions/water/WWMeasure.htm.

13. G. Grybauskaitè, D. Laurinavciene, and E. Cikockaite, The 9th International Conference "Environmental Engineering." May 22-23, 2014, Vilnius, Lithuania. Retrieved September 03, 2015 from: http://leidykla.vgtu.lt/conferences/ ENVIRO_2014/Articles/1/022_Gry bauskaite.pdf

14. M.B. Rajkovic, L. Peric, and D. Kovacevic, J. of Agricultural Sci. 47, 161 (2002).

15. Službeni list SRJ (1992): Dozvoljene kolicine metala, nemetala i nekih specificnih kontaminenata $\mathrm{u}$ namirnicama izrazene $\mathrm{u} \mathrm{mg} / \mathrm{kg}$ odn. mg/l, Broj 5, od 15.maja 1992.god., s. 83-85.

16. M. Gopalani, M.Shahare, D.S. Ramteke, and S.R. Wate, Archives of Environm. Contamin.Toxicol. 79, 384 (2007).

17. G.F. Antonious, S.O. Dennis, J.M. Unrine, and J.C. Snyder, J. Environm. Sci. and Health. Part. B, Pesticides, Food Contaminants and Agricultural Wastes 46, 112 (2011).

18. J.B.B. Silva, M.B.O. Giacomelli, I.G. Souza, and A.J. Curtius, Microchem. J. 60, 249 (1998).

19. R.F de Oliveira, C.C. Windmöller, W. Borges Neto, C. S. de Souza, M.A. Beinner, J.B.B. da Silva, Anal. Methods, 5, 5746, 2013.

20. Statistica 6.0 for Windows, StatSoft, Inc (2001) 2300 East 14th Street.

21. Z. Ajtony, N. Szoboszlai, E.K. Susko, P. Mezei, K. Gyorgy, and L. Bencs, Talanta 76, 627 (2008).

22. A.Q. Shah, T.G. Kazi, M.B. Marin, M.K. Jamali, H.I. Afridi, G.A. Kandhro, J.A. Baig, R.A .Srfraz, and R. Ansari, Food Chem. 113, 1351 (2009).

23. Association of Official Analytical Chemists (AOAC). Peer-verified Methods Program, Manual on Policies and Procedures, Arlington, VA, USA (1993).

24. P.R. Aranda, R.A. Gil, S. Moyano, I. De Vito, and L.D. Martinez, Talanta, 77, 663 (2008).

25. P.C. Aleixo, D.S. Junior, A.C. Tomazelli, I.A. Rufini, H. Berndt, and F.J. Krug, Anal. Chim. Acta 512, 329 (2004).

26. E. Bobrowska-Grzesik, and A. Jakobik-Kolon, J. of Food Compos. Anal. 21, 326 (2008).

27. P. Kalny, Z. Fijalek, A. Daszczuk, and P. Ostapczuk, Sci. Total Environm. 381, 99 (2007).

28. Z. Kilic, E. Kenduzler, and O. Acar, Food Chem. 77, 85 (2002).

29. M.B. Dessuy, M.G.R. Vale, A.S. Souza, S.L.C. Ferreira, B. Welz, and D.A. Katskov, Talanta 74, 1321 (2008). 


\section{A $_{\text {Spectroscopy }}^{\text {tomic }}$ \\ $\bigcup$ Vol. 36(6), Nov./Dec. 2015}

30. EURACHEM, The Fitness for Purpose of Analytical Methods, A Laboratory Guide to Method Validation and Related Topics (1998).

31. WHO, Food Additive Series 44: Lead (976), World Health Organization, Geneva, Switzerland (2000).

32. IGAM - Instituto Mineiro de Gestao das Aguas - Projeto "Aguas de Minas," (2009). Dados de Monitoramento em 2009. Retrieved June 31, 2012 from:

http://aguas.igam.mg.gov.br/aguas/ htmls/index.htm. 